\title{
PENGARUH JENIS BAHAN BAKAR BIOBRIKET TERHADAP UNJUK KERJA PADA MINIATUR PEMBANGKIT LISTRIK TENAGA UAP
}

\author{
Narti $^{1}$, Ihsan ${ }^{1}$, Sri Zelviani ${ }^{1}$, Nurul Wahidah ${ }^{1}$, dan Firdaus Alam Abadi ${ }^{1}$ \\ ${ }^{1}$ Jurusan Fisika, Fakultas Sains dan Teknologi, Universitas Islam Negeri Alauddin Makassar \\ email: nartinoli19@gmail.com, ihsanphysics@uin-alauddin.ac.id, sri.zelviani@uin-alauddin.ac.id, \\ nurul.wahidah@uin-alauddin.ac.id, firdaus.a.a@uin-alauddin.ac.id
}

\begin{abstract}
The research has conducted the types of bio briquette fuels on the performance of miniature Steam Powered Electric Plants (PLTU). The main component of miniature consist of the furnace, boiler, and turbine, with the dimensions around is $15 \mathrm{~cm} \times 15 \mathrm{~cm} \times 50 \mathrm{~cm}$. This study uses four fuels which are coconut shell, wood, coconut shell bio briquette, and wood bio briquette. The parameter analyzed is the electrical power produced by each of these fuels. The conclution of this researched is the type of fluid influences the performance of miniature. The highest electric power is generated by miniature with the type of fuel affects the amount of electric power produced. The biggest electric power is produced by coconut shell bio briquette with 0.0069 watt. While the smallest electric power is produced by wood fuel with a power of 0.0021 watt.
\end{abstract}

Keywords: bio briquette cconut shell, electrical power, miniatur PLTU, wood.

\section{PENDAHULUAN}

Indonesia merupakan salah satu negara yang memiliki potensi kekayaan alam dan energi yang besar, sumber daya alam yang berupa minyak bumi, gas, dan batu bara serta apabila dikelolah dan dimanfaatkan dengan baik akan mampu mencukupi kebutuhan energi masyarakat banyak. Ketiga bahan tambang ini merupakan tulang punggung pembangkitan energi listrik nasional, seperti diperlihatkan baik dalam bauran energi yang sudah dilakukan maupun dalam proyeksi bauran energi masa depan (Kumara, 2009).

Pembangkit Listrik Tenaga Uap adalah pembangkit yang mengendalikan energi kinetik dari uap untuk menghasilkan energi listrik. PLTU mengubah energi kimia dari bahan bakar menjadi energi panas yang ditransfer ke air pengisi. Bentuk utama pembangkit listrik jenis ini adalah Generator yang di hubungkan ke turbin dimana untuk memutar turbin diperlukan energi kinetik dari uap panas atau kering. PLTU menggunakan berbagai macam bahan bakar terutama batubara dan minyak bakar serta MFO untuk start awal (Yani, 2018).

Sebagian besar sumber energi listrik dihasilkan dari bahan fosil. Kurangnya sumber energi mengharuskan adanya sumber baru untuk energi listrik. Salah satu upaya untuk menghasilkan energi listrik dari sumber alternatif dan tidak ketergantungan dari sumber fosil adalah sumber energi baru yang terbarukan. 
Istilah energi terbarukan muncul saat ketersediaan energi yang berbahan dasar bahan bakar mulai mengalami penurunan. Penelitian BP Migas Indonesia menemukan bahwa hingga saat ini cadangan bahan bakar akan bertahan hingga 12 tahun kedepan, akan tetapi kebutuhan akan minyak dan gas bumi akan terus meningkat. Oleh karena itu untuk menanggulangi penurunan suplay minyak bumi dan gas ini dilakukan berbagai upaya untuk memperoleh sumber energi yang baru dan tidak mengurangi sumber daya alam yang tersedia di alam.

Menipisnya cadangan bahan bakar fosil akan berdampak pada perekonomian. Bahan bakar fosil sudah menjadi bahan bakar yang biasa digunakan untuk memenuhi kebutuhan energi dewasa ini, sedangkan para penggunanya terkadang tidak memikirkan bahwa sumber energi tersebut tidak bisa diperbaharui, untuk kembali mengisi cadangan minyak bumi diperlukan waktu yang sangat lama, sedangkan kebutuhan masyarakat akan energi tidak bisa ditunda. Ketika terjadi kelangkaan dan kenaikan harga bahan bakar mineral efeknya hampir dirasakan semua kalangan masyarakat.

Cara yang dilakukan untuk mengeliminasi kemungkinan terburuk dampak pemakaian bahan bakar fosil, setidaknya ada beberapa alternatif jalan keluar, yaitu: pencarian ladang baru, penggunaan energi secara efisien, dan pengembangan sumber energi terbarukan. Saat ini sumber yang sudah siap dan mudah didapat adalah limbah pertanian atau sampah. Biomassa yang berasal dari limbah hasil pertanian dan kehutanan merupakan bahan yang tidak berguna, tetapi dapat dimanfaatkan menjadi sumber energi bahan bakar alternatif, yaitu dengan mengubahnya menjadi biobriket. Bioarang yang dihasilkan tersebut dapat digunakan sebagai bahan bakar alternatif, yaitu pada skala rumah tangga ataupun industri.

Beberapa jenis sumber energi alternatif yang bisa dikembangkan antara lain : energi matahari, energi angin, energi panas bumi, energi panas laut dan energi biomassa. Diantara sumber-sumber energi alternatif tersebut, energi biomassa merupakan sumber energi alternatif yang perlu mendapat prioritas dalam pengembangannya dibandingkan dengan sumber energi yang lain. Di sisi lain, Indonesia sebagai negara yang agraris banyak menghasilkan limbah pertanian yang kurang termanfaatkan.

Di Indonesia sendiri sampah masih menjadi perhatian khusus dan permasalahan yang besar dalam kehidupan masyarakat terutama sampah di perkotaan seperti sampah sampah plastik yang susah terurai dengan tanah dan volume sampah yang semakin meningkat namun tempat pembuangan sampah akhir (TPA) yang terbatas.

Keterbatasan lokasi penampungan sampah juga turut menjadi salah satu kendala dalam menanggulangi banyaknya sampah yang mayoritas berasal dari kota kota besar. Melalui peraturan Presiden Nomor 18 Tahun 2016, pemerintah menetapkan percepatan pembangunan pembangkit listrik berbasis sampah menggunakan teknologi proses thermal incinerator atau pembakaran.

Penelitian tentang energi terbariukan telah berkembang hingga saat ini. Salah satunya adalah penggunaan biobriket sebagai bahan bakar alternative dalam pengeringan karet alam. Hasilnya menunjukkan bahwa biobriket dapat digunakan sebagai bahan bakar untuk pengeringan karet alam karena nilai kalor yang dihasilkan sama dengan nilai kalor batubara (Afrizal Vahlepi, 2013). 
Berdasarkan uraian sebelumnya maka pada penelitian ini penulis membuat miniatur pembangkit listrik tenaga uap dengan menggunakan pemanfaatan limbah pertanian yang diolah menjadi biobriket sebagai bahan bakar dengan judul pengaruh jenis bahan bakar biobriket terhadap unjuk kerja pada miniatur pembangkit listrik tenaga uap.

\section{METODE PENELITIAN}

Dalam melakukan penelitia ini, proses yang dilakukan beberapa tahap antara lain:

a. Mendesain alat miniatur dengan menggunakan aplikasi sketchup

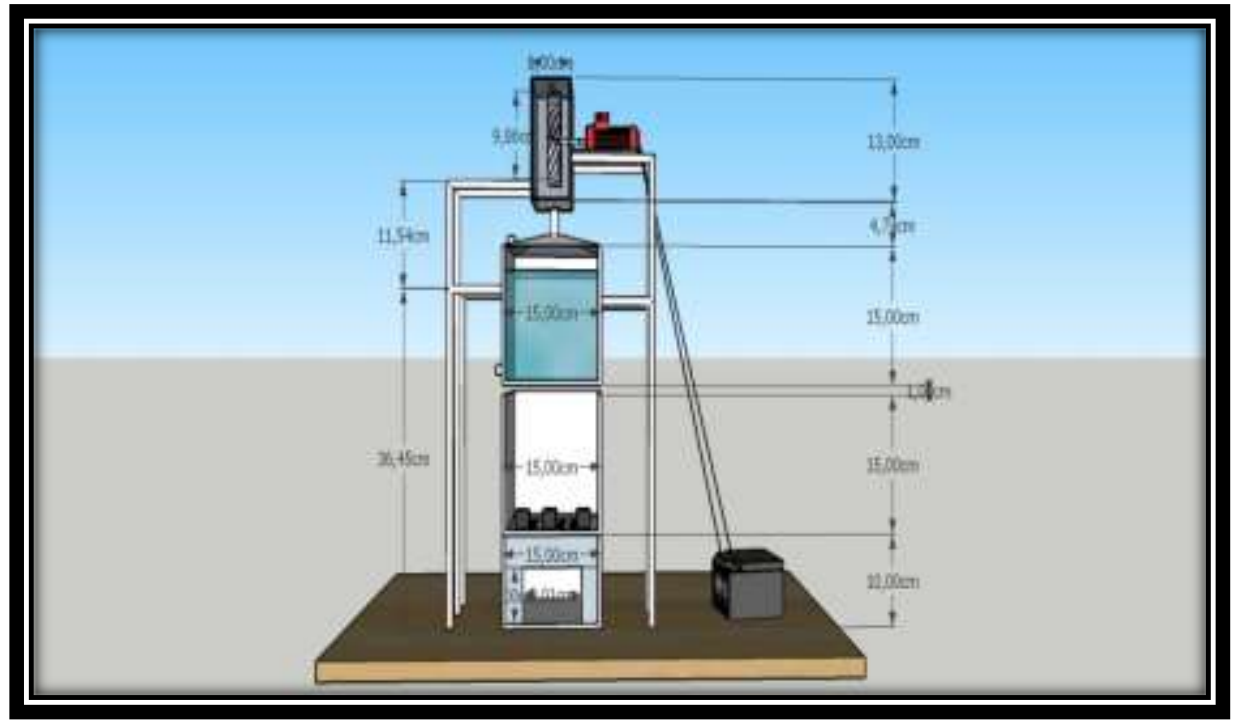

Gambar 1. Desain ukuran miniatur PLTU

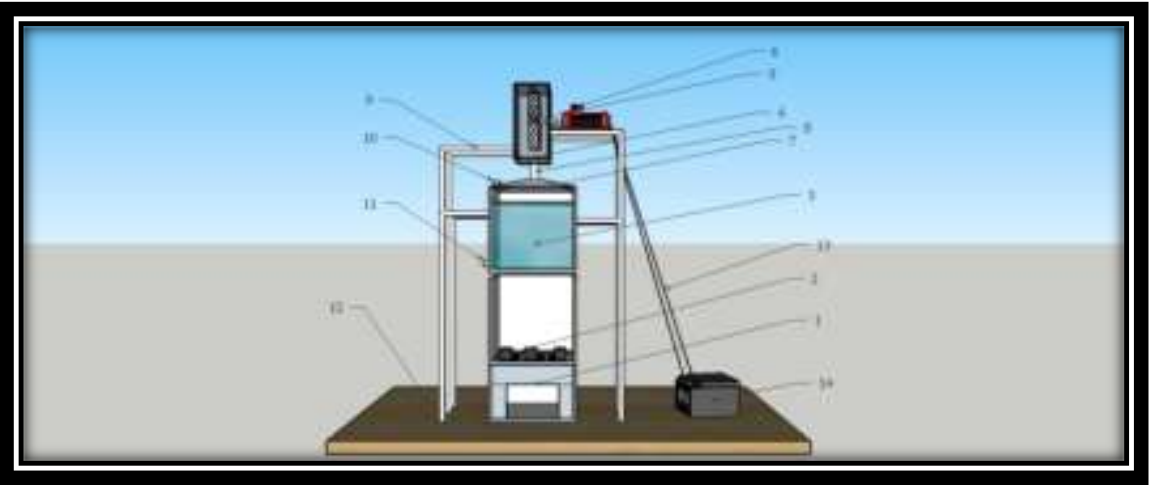

Gambar 2. Bagian-bagian miniatur PLTU 
b. Bagian-bagian miniatur

1. Banker (tempat pembakaran
briket)

2. Briket

3. Air

4. Ruang turbin

5. Turbin uap

6. Dynamo 12 volt

7. Tangki air

8. Pipa besi
9. Penyangga/kaki

10. Tempat memasukkan air (penutup)

11. Tempat pembuangan air (penutup)

12.Papan

13. Kabel penghubung

14. LED merah 1,6 volt

\section{HASIL DAN PEMBAHASAN}

Penelitian ini secara umum dibagi atas dua tahap yaitu pembuatan alat miniatur dan proses pengujian atau pengambilan data.Tahap pembuatan alat pada penelitian ini menggunakan bahan dari plat besi sebagai bahan dasar serta sebagian dari aluminium kecuali dynamo, kabel penghubung dan LED. Semua bagian direkatkan dengan menggunakan las listrik kecuali untuk bagian turbin uap yang direkatkan dengan menggunakan lem besi. Las listrik digunakan dengan tujuan agar rekatan kuat, tahan lama dan untuk menghindari adanya kebocoran pada boiler atau ketel uap.

Pada penelitian ini, menggunakan empat bahan bakar yaitu biobriket tempurung kelapa dan kayu serta bahan baku tempurung kelapa dan kayu. Dari hasil penelitian diperoleh data nilai arus dan tegangan, lama pembakaran bahan bakar sampai jadi abu serta lama waktu penguapan aquades $2000 \mathrm{ml}$ sebagai berikut:

Tabel 1. Hasil pengukuran tegangan dan arus

\begin{tabular}{|l|c|c|c|c|c|c|}
\hline \multicolumn{1}{|c|}{ Jenis Bahan Bakar } & \multicolumn{3}{|c|}{$\mathrm{I}(\mathrm{A})$} \\
\hline $\begin{array}{l}\text { Briket Tempurung } \\
\text { Kelapa }\end{array}$ & 0.988 & 1.684 & 1.889 & 0.0079 & 0.0046 & 0.0012 \\
\hline Briket Kayu & 1.557 & 1.481 & 1.478 & 0.0025 & 0.0027 & 0.0012 \\
\hline Kayu & 1.255 & 1.259 & 1.371 & 0.0029 & 0.0016 & 0.0004 \\
\hline Tempurung Kelapa & 0 & 0 & 0 & 0 & 0 & 0 \\
\hline
\end{tabular}

Tabel 2. Hasil perhitungan daya

\begin{tabular}{|l|c|c|c|}
\hline \multicolumn{1}{|c|}{ Jenis Bahan Bakar } & V (Volt) & I (A) & P (Watt) \\
\hline Briket Tempurung Kelapa & 1.5203 & 0.0046 & 0.0069 \\
\hline Briket Kayu & 1.5053 & 0.0021 & 0.0032 \\
\hline Kayu & 1.2950 & 0.0017 & 0.0021 \\
\hline Tempurung Kelapa & 0 & 0 & 0 \\
\hline
\end{tabular}


Data yang diperoleh dari hasil pengukuran arus dan tegangan dengan menggunakan empat bahan bakar dengan massa yang sama yaitu 900 gram didapatkan nilai daya berkisar antara 0,002 watt -0.007 watt. Tempurung kelapa mampu menghasilkan daya listrik tertinggi sebesar 0.0069 watt, sedangkan bahan baku kayu mampu menghasilkan daya listrik terendah sebesar 0.002 watt. Hal ini dipengaruhi oleh besarnya nilai kalor dari bahan bakar tersebut. Dimana nilai kalor tertinggi dimiliki biobriket tempurung kelapa sebesar $5.779 \mathrm{kal} / \mathrm{g}$, biobriket kayu memiliki nilai kalor sebesar 4.491,2 kal/g sedangkan nilai kalor terendah dimiliki bahan baku kayu dan tempurung kelapa sekitar $3.000 \mathrm{kal} / \mathrm{g}$. Nilai kalor yang tinggi akan membuat pembakaraan menjadi lebih efisien dan dapat menghemat kebutuhan briket yang digunakan.

Pengaruh bahan bakar terhadap daya listrik dapat dilihat pada grambar 3 . Daya listrik dipengaruhi oleh besarnya nilai kalor dari bahan bakar. Dimana semakin tinggi nilai kalor suatu bahan bakar maka daya listrik yang dihasilkan akan semakin besar pula.

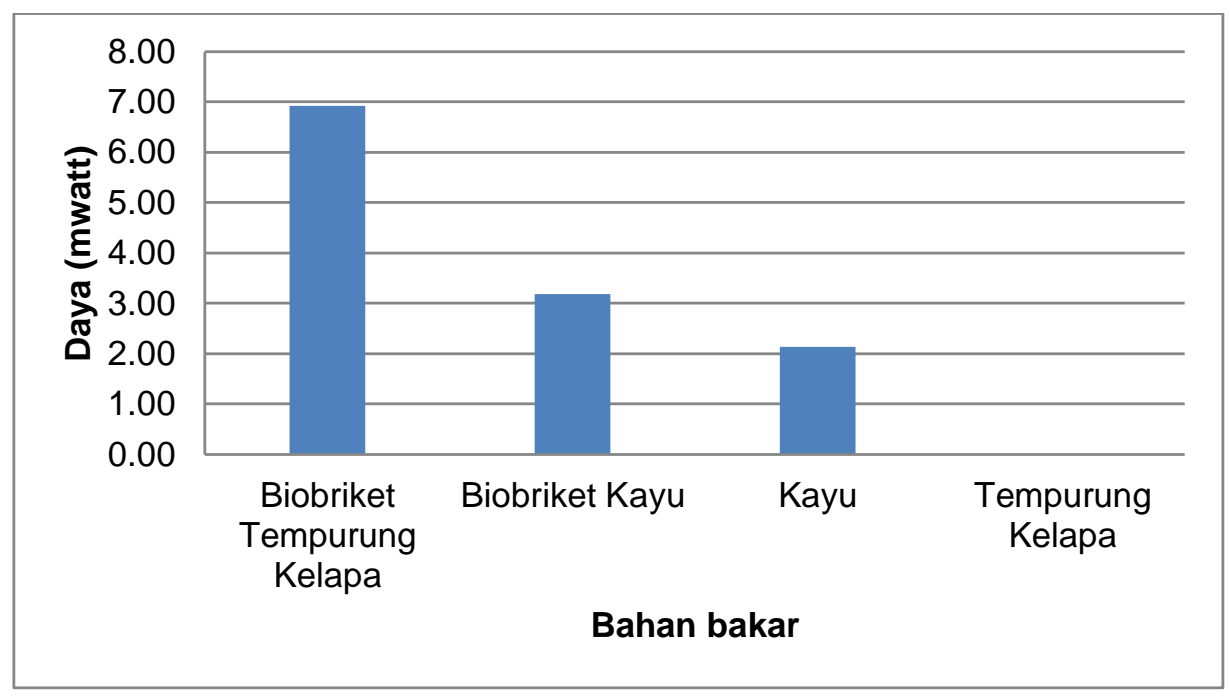

Gambar 3. Grafik hubungan antara bahan bakar terhadap daya (mwatt)

Dari hasil pengukuran arus dan tegangan diketahui bahwa pada jenis bahan bakar bahan baku tempurung kelapa tidak menunjukkan perputaran turbin uap sehingga tidak dapat mengukur daya. Hal ini disebabkan karena pada saat pembakaran tempurung kelapa di dalam kompor briket hanya menghasilkan jelaga atau jumlah asap yang banyak. 


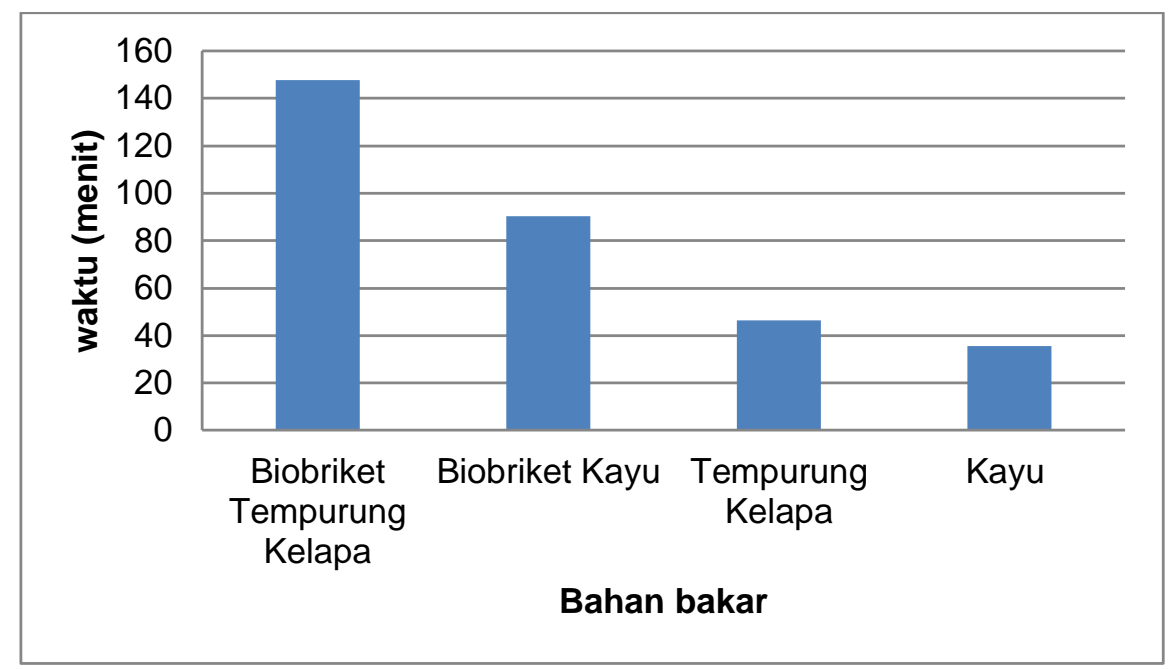

Gambar 4. Grafik pengaruh bahan bakar terhadap lama penyalaan sampai jadi abu (menit)

Lama pembakaran untuk masing-masing jenis biobriket dan bahan baku dapat dilihat pada tabel 3. Dari gambar 4 dapat diketahui bahwa biobriket tempurung kelapa memberikan nyala bara sampai menjadi abu terlama yaitu 147,75 menit dengan massa 900 gram Sementara lama pembakaran yang paling cepat habis adalah bahan baku kayu dengan waktu 35,46 menit dengan massa 900 gram. Lama waktu pembakaran dipengaruhi oleh struktur bahan, kandungan karbon terikat dan tingkat kepadatan bahan.

Secara teoritis jika briket memiliki kandungan senyawan volatile (zat yang mudah menguap) yang tinggi, maka briket akan mudah terbakar dengan kecepatan pembakaran tinggi. Semakin besar nilai kalor bahan bakar maka kecepatan pembakaran semakin lambat. Hal ini dibuktikan pada gambar 12 bahwa biobriket tempurung kelapa dengan nilai kalor $5.779 \mathrm{kal} / \mathrm{g}$ membutuhkan waktu terlama hingga menjadi abu yaitu 147,75 menit. Sedangkan bahan baku kayu membutuhkan waktu tercepat untuk menjadi abu karena bahan kayu memiliki tekstur yang kering dan mudah terbakar dibandingkan dengan bahan baku tempurung kelapa yang memiliki tekstur yang keras.

Dalam penelitian yang dilakukan Siti Jamilatun (2008), mengenai "Sifat-Sifat Penyalaan dan Pembakaran Briket Biomassa, Briket Batubara dan Arang Kayu" Hasil penelitian menunjukkan bahwa tempurung kelapa dengan berat briket yang terbakar memiliki lama pembakaran terpanjang yaitu 116 menit dengan kecepatan pembakaran 126,6 gram/detik. Sementara nyala bara yang paling cepat habis adalah briket batubara terkarbonisasi dengan waktu 60,57 menit. 


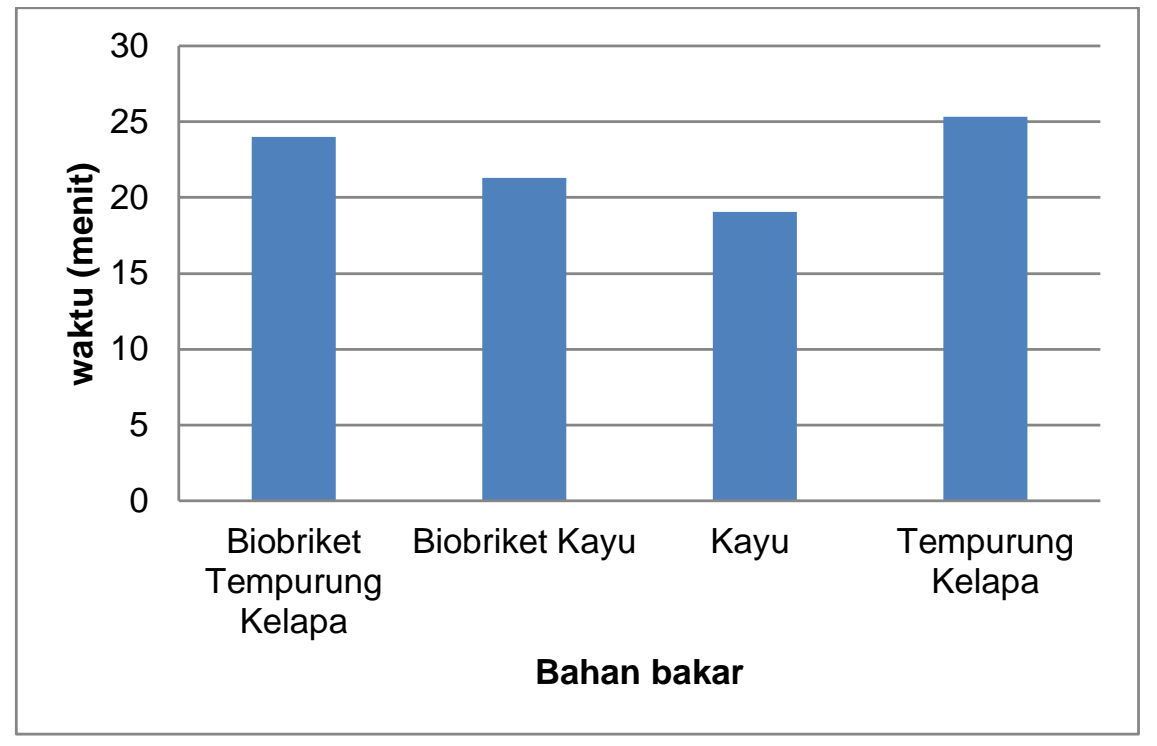

Gambar 5. Grafik pengaruh bahan bakar terhadap waktu penguapan aquadest $2000 \mathrm{ml}$ (menit)

Pengaruh bahan bakar terhadap waktu penguapan aquades dapat dilihat pada gambar 5 terlihat bahwa semua jenis bahan bakar yang digunakan membutuhkan sekitar 19 menit sampai dengan 25 menit untuk menguapkan 2000 $\mathrm{ml}$ aquades. Limbah kayu mampu menguapkan aquades tercepat yaitu 19,05 menit. Hal ini disebabkan karena kayu yang digunakan memiliki bahan yang cukup kering sehingga mudah terbakar dengan nyala api yang besar dan tingkat kemudahan penyalaan awal yang paling mudah yang hanya membutuhkan waktu sekitar 20 detik.

Sedangkan untuk bahan bakar yang paling lama menguap adalah bahan baku tempurung kelapa dengan lama waktu 25,35 detik. Hal ini disebabkan karena tempurung kelapa ketika terbakar lebih banyak menghasilkan asap dan nyala api yang kecil. Sedangkan untuk biobriket tempurung kelapa dengan selisi waktu 1,35 menit dengan bahan baku tempurung kelapa yaitu 24 menit. Hal ini disebabkan karena pada biobriket tempurung kelapa mengalami tingkat penyalaan awal yang sulit sehingga membutuhkan waktu yang lama untuk bisa berbara.

Lama penyalaan pada biobriket tempurung kelapa disebabkan oleh bentuk biobriket yang berbentuk kotak sehingga ketika berada di kompor briket susunannya akan rapat dan tidak ada rongga untuk tempat menyala api. Sedangkan untuk biobriket kayu yang membutuhkan waktu 21.32 menit saat terjadinya penguapan. Hal ini disebakan karena waktu penyalaan awal tidak membutuhkan waktu yang lama seperti halnya dengan biobriket tempurung kelapa karena biobriket kayu berbentuk hexagonal atau segi enam sehingga mempermudah saat penyalaan awal dimana ketika disusun di kompor briket memiliki ruang atau rongga udara untuk api menyala, namun ketika berbara hanya mengasilkan bara api yang sedang dan memiliki jumlah abu yang lebih banyak daripada biobriket tempurung kelapa. 
Berdasarkan hal tersebut dapat disimpulkan bahwa dari hasil pembakaran biobriket tempurung kelapa maupun biobriket kayu lebih ramah lingkungan, relatif cukup baik digunakan sebagai bahan bakar alternative yang ekonomis serta tidak menyebabkan polusi udara jika dibandingkan dengan bahan baku kayu dan tempurung kelapa.

\section{SIMPULAN}

Berdasarkan penelitian yang telah dilakukan dapat disimpulkan bahwa jenis bahan bakar mempengaruhi besar daya listrik yang dihasilkan. Daya listrik terbesar dihasilkan oleh bahan bakar biobriket tempurung kelapa sebesar 0,0069 watt. Sedangkan daya listrik terkecil dhasilkan oleh bahan bakar kayu dengan daya sebesar 0,0021 watt.

\section{DAFTAR PUSTAKA}

Adzikri, Fikry, Didik Notosudjono, \& Dede Suhendi. 2008. Strategi Pengembangan Energi Terbarukan di Indonesia. Program Studi Teknik Elektro, Fakultas Teknik:Universitas Pakuan.

Isarani, Ismail Yusuf, Kho Hie Kwee. 2015. Analisis Kinerja Pembangkit Listrik Tenaga Uap Biomassa Menggunakan Limbah Kayu (Studi Kasus : PT. Suka Jaya Makmur Ketapang). Universitas Tanjungpura Pontianak.

Kumara, Nyoman S. 2009. Telaah Terhadap Program Percepatan Pembangunan Listrik Melalui Pembangunan PLTU Batubara 10.000 Mw. Bali. Jurnal Teknologi Elektro Vol. 8 No.1.

Vahlepi A, Suwardin D. 2013. Penggunaan biobriket sebagai bahan bakar alternative dalam pengeringan karet alam. Warta Perkaretan 32(2), 65-73.

Yani, Ahmad, Dedi Mustafa, Taqwa. 2018. Rancang bangun prototype pembangkit listrik tenaga Uap mini sebagai media praktikum mahasiswa. Kalimantan Timur. Jurnal Teknik Mesin Vol. 7 No. 1. 